\title{
Study of Commitment to The Organization Based on Intrinsic and Extrinsic Job Satisfaction on Private Campus
}

\author{
Wasi Bagasworo \\ STIE Indonesia Banking School \\ wasi.bagasworo@ibs.ac.id
}

\begin{abstract}
Competition in education industry especially college is very tight. It is experienced by STIE XYZ which does not reach the target of new student admission in 2015 and 2016. Unachieved student targets are added to the level of student discharge at the 2 nd level of $10-15 \%$ of the total students of the first batch. One of the causes of the decline and discharge rate of students is possible because of student dissatisfaction. The organizational commitment questionnaire (OCQ) designed by Allen \& Mayer (1990) is enhanced by Ikwukananne I. Udechukwu (2006) used as a measurement tool for affective commitment, continuance commitment and normative commitment. This study is descriptive by using questionnaire respondents as much as population of 39 permanent employees of STIE XYZ in 2015. The data were processed using SPSS 21 for instrument test, classical assumption test and hypothesis test with t-test. The results show that commitment to the organization is positively influenced by inner job satisfaction and is not influenced by extrinsic job satisfaction. In intrinsic job satisfaction that needs to be considered is the issue of security / stability and job authority. Some suggestions that can be done is to provide a clear job description and standard operating procedures when employees occupy job positions, career paths for employees, job rotation based on employee competence and the need for information disclosure according to procedures and authority.
\end{abstract}

Keywords: commitment to organization, intrinsic job satisfaction, extrinsic job satisfaction

\begin{abstract}
Abstrak
Persaingan di industri pendidikan khususnya perguruan tinggi sangat ketat. Hal ini dialami oleh STIE XYZ yang tidak mencapai target penerimaan siswa baru pada tahun 2015 dan 2016. Target siswa yang tidak tercapai ditambahkan ke tingkat debit siswa pada tingkat kedua sebesar 10-15\% dari total siswa angkatan pertama. Salah satu penyebab penurunan dan tingkat debit siswa adalah mungkin karena ketidakpuasan siswa. Kuesioner komitmen organisasional yang dirancang oleh Allen \& Mayer (1990) ditingkatkan oleh Ikwukananne I. Udechukwu (2006) digunakan sebagai alat ukur untuk komitmen afektif, komitmen kontinuitas, dan komitmen normatif. Penelitian ini bersifat deskriptif dengan menggunakan kuesioner responden sebanyak populasi 39 pegawai tetap STIE XYZ pada tahun 2015. Data diolah dengan menggunakan SPSS 21 untuk uji instrumen, uji asumsi klasik dan uji hipotesis dengan uji-t. Hasil penelitian menunjukkan bahwa komitmen terhadap organisasi dipengaruhi secara positif oleh kepuasan kerja batin dan tidak dipengaruhi oleh kepuasan kerja ekstrinsik. Dalam kepuasan kerja intrinsik yang perlu diperhatikan adalah masalah keamanan / stabilitas dan otoritas kerja. Beberapa saran yang dapat dilakukan adalah memberikan gambaran pekerjaan yang jelas dan prosedur operasi standar saat karyawan menempati posisi pekerjaan, jalur karir untuk karyawan, rotasi kerja berdasarkan kompetensi pegawai dan kebutuhan pengungkapan informasi sesuai prosedur dan kewenangan.
\end{abstract}

Kata Kunci: komitmen terhadap organisasi, kepuasan kerja intrinsik, kepuasan kerja ekstrinsik

\section{Introduction}

Competition in education industry especially college is very tight. This is because many universities, both private and domestic, are in one region, especially in Java, DKI Jakarta. Table 1 shows the distribution of universities in DKI Jakarta. South Jakarta area as an area of STIE XYZ has a second level of competition for high school campus after East Jakarta area. This condition makes the competition in getting new students in every academic year is increasingly competitive. It is experienced by STIE XYZ which does not reach the target of new student admission in 2015 and 2016. In Addition the level of student discharge at the 2nd level of $10-15 \%$ of the total students of the first batch. Based on interview with student, one of the causes of the decline and discharge rate of students is possible because of the dissatisfaction of students to education services in STIE XYZ, especially services provided by permanent employee. This is in line with the opinion of Morris (1995) which states that employee satisfaction is an important factor that affects customer satisfaction where employees who have job satisfaction will job well, especially employees who serve consumers. Increased job satisfaction will increase employee commitment to STIE XYZ so that employees are expected to job well and last long in the organization so that there are not many turn over employees that harm the organization. This condition will assist STIE XYZ in dealing with organizational problems and achieving its objectives. The authors limit the research on job satisfaction to the commitment of the permanent employee organization of STIE XYZ who has worked for more than three months or have passed the trial period of job. Because if the employee has passed the probation period, 
Table 1. Number of Universities by Region

\begin{tabular}{lcccccc}
\hline \multicolumn{1}{c}{ Region/City } & University & Institute & $\begin{array}{c}\text { High School } \\
\text { Campus }\end{array}$ & Academy & Polytechnic & Amount \\
\hline West Jakarta & 8 & 1 & 17 & 10 & 0 & 36 \\
Central of Jakarta & 4 & 1 & 23 & 17 & 1 & 46 \\
North Jakarta & 2 & 1 & 6 & 6 & 1 & 16 \\
East Jakarta & 16 & 2 & 50 & 50 & 2 & 120 \\
South Jakarta & 16 & 3 & 42 & 30 & 5 & 96 \\
Bekasi & 0 & 0 & 1 & 0 & 0 & 1 \\
Depok & 1 & 0 & 1 & 2 & 0 & 4 \\
Tangerang & 2 & 1 & 3 & 0 & 0 & 6 \\
\hline \multicolumn{1}{c}{ TOTAL } & $\mathbf{4 9}$ & $\mathbf{9}$ & $\mathbf{1 4 3}$ & $\mathbf{1 1 5}$ & $\mathbf{9}$ & $\mathbf{3 2 5}$ \\
\hline
\end{tabular}

Source: https://kopertis3.or.id

it is assumed in general they have obtained satisfaction / dissatisfaction from the results of his job as a whole.

Based on the above background, the authors formulate the research question as follow:

1. Is there a positive influence between intrinsic job satisfaction on organizational commitment to permanent employees of STIE XYZ?

2. Is there any positive influence between extrinsic job satisfaction to organizational commitment to permanent employees of STIE XYZ?

3. Which job satisfaction dominates the influence on organizational commitment to permanent employees of STIE XYZ?

\section{Literature Review \\ Organizational commitment}

In the perspective of organizational performance, commitment to the organization is defined as an accompanying psychological factor in shaping relationships between employees and organizations (Reio \& Thomas, 2012; Crow, Lee \& Joo., 2012). The result of the relationship can increase employees' commitment to their organization (Hyun-Woo et al., 2015; Kasim \& Ghaffar, 2012).

Allen and Mayer (1990) identify three types that can define commitment:

1. Affective commitment, is the level of psychological relevance with the organization based on how good the feelings about the organization. Affective commitment arises and evolves by the encouragement of comfort, security, and other perceived benefits in an organization not obtained from other places or organizations.

2. Continuance commitment, an association of members psychologically to the organization because of the costs that he assumes as a consequence out organization. In this connection members will calculate the benefits and sacrifices of involvement in or membership of an organization. Members will tend to have a high endurance or commitment in membership if the sacrifice resulting from outgoing organizations is higher.

3. Normative commitment, an association of members psychologically with the organization because of the moral obligation to maintain relationships with the organization. In this connection something that encourages members to remain and contribute to the existence of an organization, both material and non-material, is the existence of a moral obligation, in which one will feel uncomfortable and guilty if not doing something.

Measuring tool in this research using measuring instrument in research Ikwukananne I. Udechukwu (2006) which refers to Allen and Mayer (1990).

\section{Intrinsic satisfaction}

Herzberg (1959) states that the conceptual job satisfaction consists of two factors, namely the intrinsic job satisfaction and extrinsic job satisfaction. Other names of extrinsic factors are dissatisfaction, hygiene factors, and job context, while intrinsic factors have other names of satisfiers, motivators, and job content. Intrinsic job satisfaction reflects that employees actually do their job and feel successful and gain self-actualization from the employee's own experience. Part of intrinsic factor is activity, independence, diversity, social status, moral value, security, social service, authority, ability utilization, responsibility, creativity, and achievement. (Yu-Ching Huang, 2004). Several studies have shown that the effect of intrinsic job satisfaction on organizational commitment is Ismail \& Razak (2016) and Zakkariya (2015) research, which explains the effect of intrinsic job satisfaction on organizational commitment. The result of Gunlu's research (2010) stated that there is a positively significant influence between intrinsic job satisfaction toward affective commitment and has a positively significant influence between intrinsic job satisfaction toward Normative Commitment.

\section{Extrinsic satisfaction}

Extrinsic job satisfaction refers more to the rewards given by the company to its employees, which can be in the form of compensation and job security. As part of extrinsic factors are supervisory and human relationships, 


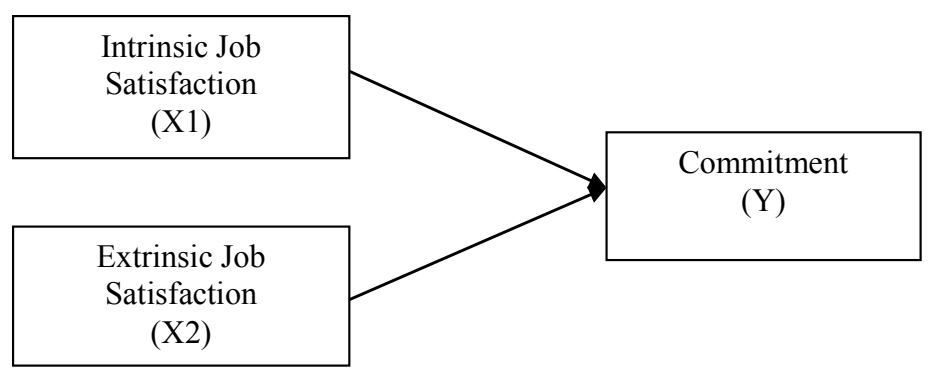

Figure 1. Research Model

supervision techniques, company policies, compensation, progress, jobing conditions, co-jobers and recognition. (Yu-Ching Huang, 2004). Several studies showing the effect of extrinsic job satisfaction on organizational commitment are Ismail \& Razak (2016), Yu-Ching Huang (2004) and Samuel \& Twaha (2014) study which proves that the organization's ability to plan and execute external job factors (ie , compensation, interpersonal relations, supervision, policy and administration, security and health, opportunities for continued growth, social integration, constitutionalism in job organization, job and total living space, social relevance of job life, status and job security) will lead to attitudes and behaviors employee effects to support the organization's strategy and goals.

Based on the literature and referring to Ismail \& Razak (2016) research as a replication of this research model, this research model can be seen in Figure 1. The hypothesis formed based on the research model:

\section{Hypothesis 1}

Ho1: The variable of intrinsic job satisfaction has no significant effect on the commitment of permanent employees of STIE XYZ

Ha1: The variable of intrinsic job satisfaction has a significant influence on the commitment of permanent employees of STIE XYZ

\section{Hypothesis 2}

Ho2: The variable of extrinsic job satisfaction has no significant effect on the commitment of permanent employees of STIE XYZ

Ha2: The variable of extrinsic job satisfaction has a significant influence on the commitment of permanent employees of STIE XYZ

\section{Research Methods}

This study uses a quantitative approach where the data is qualitative translated into quantitative figures in order to be analyzed using statistics. The results of statistical analysis are translated back into qualitative language to be more easily understood by those who need it. This research uses descriptive research type. According to Malhotra (2010) descriptive research is a kind of conclusive research that aims to describe/describe a character/characteristic or function of something. The object of this study is permanent employees (educational staff not lecturer) who have passed the probation period at STIE
XYZ. Method of primary data collection needed for this study was conducted by questionnaire (questionnaire), spreading a set of questions that have been prepared by the author to the respondents directly to be filled in correctly. In preparing the kuesionare, researchers used a likert scale to measure the variables associated with the study. This scale uses five points on both ends of the label with the provision getting closer to the tip of point 1 means strongly disagree, while getting closer to the tip of point 5 means strongly agree. Measuring tool used in this research can be seen in table 2 .

\section{Results and Discussion \\ Characteristics of Respondents}

Male sex respondents dominate in this research, 56\% of respondents are male, the rest is $44 \%$ women. Based on data from 39 respondents, it can be seen that $51 \%$ are 20-30 years old, $23 \%$ are $31-40$ years old, $15 \%$ are $41-50$ years old and $8 \%$ are over 50 years old. Based on data from 39 respondents, $33 \%$ of respondents are in jobing period of $1-2$ years, $31 \%$ in jobing period $>5$ years, $15 \%$ in jobing period $4-5$ years, $8 \%$ at $0-1$ years jobing period, $8 \%$ in jobing period $4-5$ years and $5 \%$ in jobing period of 2-3 years. The composition of the positions of 39 respondents is as follows: $79 \%$ are staff, $5 \%$ are session heads, and $8 \%$ are heads of departments.

\section{Analysis of research results \\ Validity Test}

The validity of an indicator can be declared valid when $r$ count $>r$ table. If $r$ value of $95 \%$ (significance $5 \%$ ) is known with 1 way test and $n=38$ then $r$ table $=$ 0.263 . The result of validity test shows that for commitment variable, valid measuring instrument / indicator is $\mathrm{AC} 1$ and AC5. Valid indicators / indicators of valid inner job satisfaction variables are KI6 and KI8 while the valid extrinsic satisfaction measure / indicator variable is KE3, KE7, and KE8.

\section{Test of reliability}

The measurement variable can be said reliably if the alpha value is greater than the critical product moment $r$. Reliability less than 0.6 is less good, while 0.7 is acceptable and above 0.8 is good. Based on the test results it can be seen that the indicators AC1, KI6, KE7 and KE8 have a value of cronbach's alpha below 0.6 which means less good reliability even though the value close to 0.6 . Indicator AC5, KI8, KE3 has a value above 0.6 which means its reliability is acceptable.

\section{Normality Test}

Based on the results of normality testing using non parametric techniques Kolmogorov-Smirnov (K-S) with 
Table 2. Variable Operations

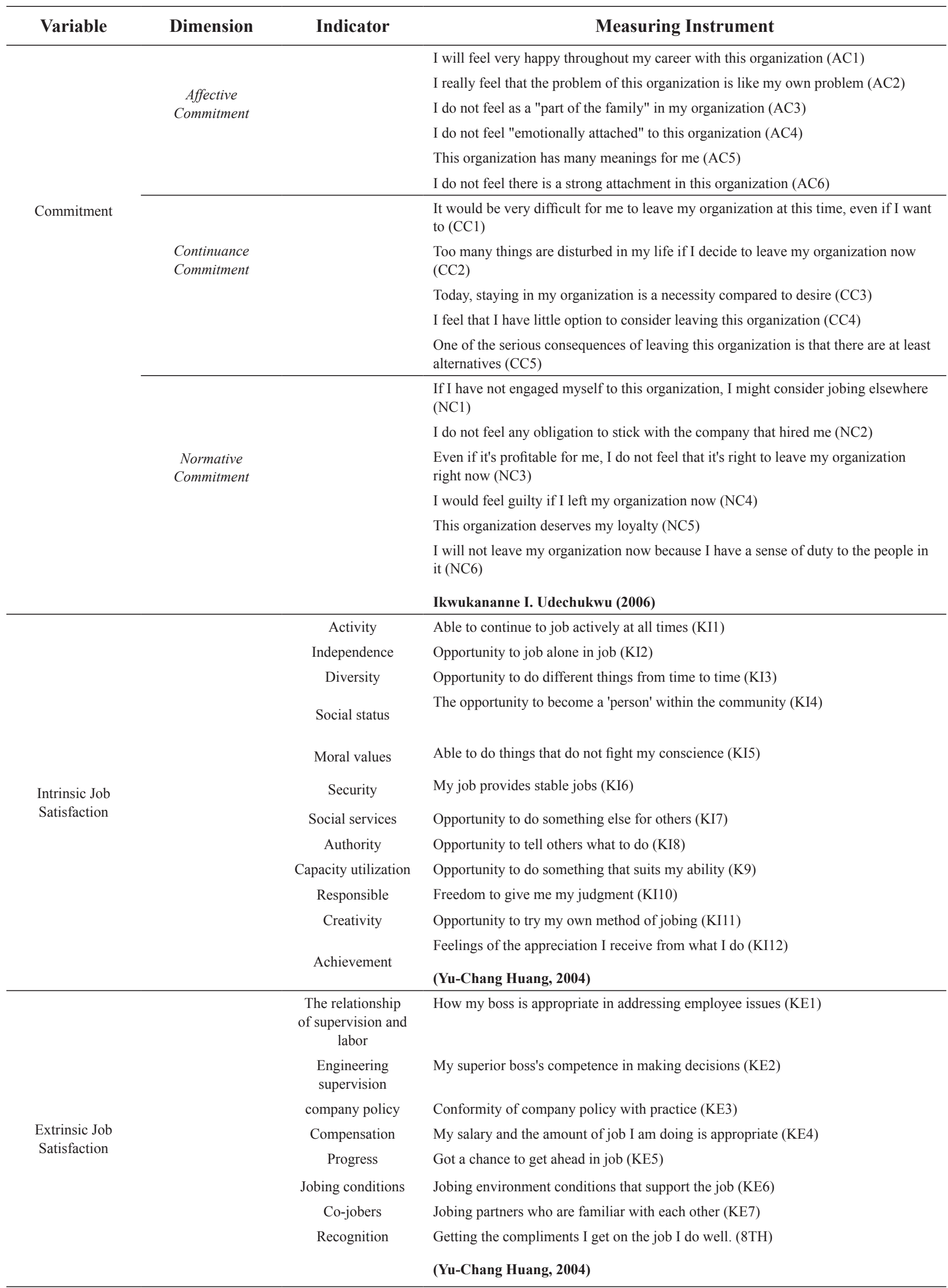


Table 3. Test Results $\mathrm{t}$

Coefficients $^{\mathrm{a}}$

\begin{tabular}{|c|c|c|c|c|c|c|c|c|}
\hline \multirow[t]{2}{*}{ Model } & & \multicolumn{2}{|c|}{$\begin{array}{c}\text { Unstandardized } \\
\text { Coefficients }\end{array}$} & \multirow{2}{*}{$\begin{array}{c}\text { Standardized } \\
\text { Coefficients } \\
\text { Beta }\end{array}$} & \multirow[t]{2}{*}{$\mathrm{t}$} & \multirow[t]{2}{*}{ Sig. } & \multicolumn{2}{|c|}{$\begin{array}{l}\text { Collinearity } \\
\text { Statistics }\end{array}$} \\
\hline & & B & Std. Error & & & & Tolerance & VIF \\
\hline & (Constant) & 1.723 & .467 & & 3.693 & .001 & & \\
\hline 1 & $\mathrm{KI}$ & .387 & .130 & .482 & 2.986 & .005 & .852 & 1.174 \\
\hline & $\mathrm{KE}$ & -.020 & .102 & -.032 & -.198 & .844 & .852 & 1.174 \\
\hline
\end{tabular}

a. Dependent Variable: COM

unstandardized residual value obtained Asymp value. Sig. of 0.963 . The terms of data are said to be normal when the value of Asymp. Sig. greater than 0.05 , in other words in this study the data is normally distributed due to the value of Asymp. Sig. greater than 0.05 ie 0.963 ..

\section{Heteroscedasticity Test}

Based on the test results known that the signification of internal satisfaction variables $(\mathrm{KI})=0.689$ and external satisfaction $(\mathrm{KE})=0.504$ so as to avoid heteroskedastisitas because the value of sig $>0.05$.

\section{Multicollinearity Test}

Based on table 3 we can know that VIF value for Internal Job Satisfaction (KI) is less than 10 that is 1,174 and also VIF value for External Job Satisfaction also less than 10 that is 1.174 . VIF value of all variables that exist under 10 then it can be concluded that no symptoms of multicollinearity

\section{Hypothesis testing}

Test $t$

Based on table 2 shows that the value of Sig. for Internal Job Satisfaction (KI) variable is $0.005 \leq 0.05$, which means Internal Job Satisfaction variable (KI) has a significant influence on Jobing Employee Commitment in STIE XYZ so that H0 is rejected. Then the value of Sig. for External Job Satisfaction variable (KE) of 0.844> 0.05 , which means that External Job Satisfaction variable (KE) has no significant effect on Employee Permanent Jobing Commitment in STIE XYZ so that HO is accepted.

\section{Test $F$}

How to determine the accuracy of the above model, ie by comparing the probability (Sig.) With alpha (0.05)
- If the probability is $>0.05$ then the model is rejected

- If the probability is $<0.05$ then the model is accepted

Based on table 4 shows the probability (sig) is worth $0.012<0.05$ so that the model in this study is accepted.

\section{Regression Equation Model}

The regression equation model for this study refers to table 4 where the regression equation is as follows:

Commitment $=1.723+0.387$ Internal Job Satisfaction( KI) - 0.020 External Job Satisfaction KE)

The regression coefficient of Internal Job Satisfaction (KI) of 0.387 with positive sign indicates that the KI variable is directly proportional to the level of Job Commitment (KOM) while the regression coefficient of External Job Satisfaction (KE) of - 0.020 is negative signified that the $\mathrm{KE}$ variable is negative compared to the level of Job Commitment KOM) and has no effect based on the results of the previous $t$ test. The dominant influence on commitment is internal job satisfaction. The constant of 1,723 marked positive means that if there is no KI and $\mathrm{KE}$ then the value of KOM is 1.723 .

\section{Coefficient of Determination (Adjusted R2)}

Determination coefficient analysis (R2) is used to test the extent to which variations of independent variables are able to explain the dependent variable. The value used is Adjusted R Square as the coefficient of determination is the result of calculation R2. Based on table 5 we can know that adjusted R2 of 0.177 . This means that the independent variables of Internal Job Satisfaction (KI) and External Job Satisfaction (KE) only have an effect of $17.7 \%$ on Job Commitment (KOM), the rest of $82.3 \%$

Table 4. F Test Results

\begin{tabular}{rlrrrrr}
\multicolumn{7}{c}{ ANOVA $^{\mathbf{a}}$} \\
Model & & \multicolumn{1}{c}{ Sum of } & df & Mean Square & F & Sig. \\
& & Squares & & & & \\
\hline \multirow{3}{*}{1} & Regression & 2.039 & 2 & 1.019 & 4.988 & $.012^{\mathrm{b}}$ \\
& Residual & 7.152 & 35 & .204 & & \\
& Total & 9.191 & 37 & & & \\
\hline
\end{tabular}

a. Dependent Variable: COM

b. Predictors: (Constant), KE, KI 
Table 5. Results of Coefficient of Determination

\begin{tabular}{lrrrr}
\multicolumn{5}{c}{ Model Summary } \\
\hline Model & R & R Square & $\begin{array}{c}\text { Adjusted R } \\
\text { Square }\end{array}$ & $\begin{array}{l}\text { Std. Error of } \\
\text { the Estimate }\end{array}$ \\
\hline 1 & $.471^{\mathrm{a}}$ & .222 & .177 & .452 \\
\hline
\end{tabular}

a. Predictors: (Constant), KE, KI

influenced by other factors not examined in this study.

\section{Managerial Implications}

Based on the results of the Average Value calculation, the researchers set the steps of managerial implications as follows:

1. Establish the variables that affect job commitment as the basis of managerial implications for this research. This research resulted that only variable of intrinsic job satisfaction influenced job commitment to permanent employee at STIE XYZ.

2. Establish the dominant variable as a priority of managerial implications that STIE XYZ can perform. The dominant variable in this study is only the variable of intrinsic job satisfaction (KI) because the only variable influencing job commitment (KOM).

3. Setting the lowest average indicator value as a matter of concern in the managerial implications of STIE XYZ. The lowest indicator is KI6 worth 3.49 and KI8 worth 3.61.

4. Indicators on dominant variables will be specified into suggestions that can be applied by STIE XYZ. The emphasis of managerial implications on KI6 namely Security and KI8 is Authority.

The safety factor in job which is reflected in the statement "my job provides stable jobs" has the lowest value even though it is still within the neutral value or $=3$. This may be due to the condition can't be too objective and the fear of the answer based on the characteristics of respondents who have a staff employee of $79 \%$. Concerns about instability in job should be addressed by the management of STIE XYZ by doing the following:

1. Provide detailed employment regulation through Collective Job Agreement/Foundation Decree signed by both parties so that the rights and obligations of employees can be known and executed properly.

2. Provide assurance in career ladder for employees who have long career in XYZ so they feel there is stability in its job seen from career ladder in job.

3. The transfer of employees to other departments/ units should be done based on the competence and job experience of the employees. This is useful for employees in stability in the type / position of job and is useful for the institution not to waste time learning for employees in learning new jobs that will affect the job process in the new job unit employees concerned.

The authority factor reflected in the statement (the opportunity to tell others what to do" has the second lowest value) to be noticed by the management of STIE XYZ. Some of the things that can be done by institutional management are as follows:

1. The clarity in the authority reflected in the job description of any job in the STIE XYZ needs to be elaborated in the Collective Job Agreement/Foundation Decree so that employees and institutions can know the limits of authority from each position/job position.

2. Consistency in running Standard Operation Procedure (SOP) without exception either from employees or institutional management. The importance of this consistency needs to be done especially the management of the institution as it will become an example for employees to job according to the SOP that has been agreed upon.

3. The need for organizational culture in terms of openness based on existing rules/mechanisms and facts without the need for fear to inform management or employees so as to increase the opportunity to inform others what to do procedurally and authority for the good of the institution.

Several strategies for improving the intrinsic satisfaction indicators are expected to increase employee commitment to STIE XYZ. Low indicator of employee commitment and expected to increase with the implementation of some managerial implications above is an AC5 indicator (I do not feel there is a strong attachment in this organization) with an average value of 2.56 which means employees do not feel any strong ties with STIE XYZ.

\section{Conclusions and recommendations Conclusion}

Based on the study of theories relating to research and perform data analysis in the previous chapters, the researchers get the following conclusions.

1. There is a significant positive influence of intrinsic job satisfaction on organizational commitment to permanent employees of STIE XYZ.

2. There is no significant positive effect of extrinsic job satisfaction on organizational commitment to permanent employees of STIE XYZ.

3. The dominant factor affecting organizational com- 
mitment in this research is the intrinsic job satisfaction so that the involvement of institutional management is needed in improving the indicators in the job satisfaction of the intrinsic.

\section{Suggestion}

Some suggestions that can be done by STIE XYZ are:

1. Provide detailed employment regulation through Collective Job Agreement (KKB) / Foundation Decree signed by both parties so that the rights and obligations of employees can be known and executed properly. Where in the KKB / Foundation Decree must be attached rights and obligations, authority / responsibility (Job Description) and Standard Operation Procedure (SOP) clearly accompanied by punishment and reward in the implementation of such job.

2. Provide assurance in career ladder for employees who have long career in $\mathrm{XYZ}$ so they feel there is stability in its job seen from career ladder in job. The career path can be explained on the organizational structure that employees should know and explanation of the career achievement.

3. The transfer of employees to other sections / units should be done based on the competence and job experience of the employees so that employees do not need long time to adjust so as to reduce coordination and communication with colleagues' part / new unit.

4. The need for organizational culture in terms of openness based on existing rules / mechanisms and facts without the need for fear to inform management or employees so as to increase the opportunity to inform others what to do procedurally and authority for the good of the institution.

\section{Reference}

Allen, J. Natalie., \& John P. Meyer. (1990). "The measurement and Antecedents of Affective, Continuance and Normative Commitment to the Organization". Journal of Occupational Psychology, 63, 1-18.

Crow, Matthew S., Chang-Bae Lee \& Jae-Jin Joo. (2012). Organizational justice and organizational commitment among South Korean police officers. Policing: An International Journal of Police Strategies \& Management, Vol. 35 Iss 2 pp. 402-423.

Ebru Gunlu and Mehmet Aksarayli. (2010). Job Satisfaction and Organizational Commitment of Managers Hotel in Turkey. International Journal of Contemporary Hospitality Managment. Volume 22 No. 5 of 2010. Navsehir University, Turkey.

Herzberg F., Mausner B., Synderman B. (1959). The motivation to work. New York: Wiley.

Hyun-Woo Joung Ben K. Goh Lynn Huffman Jingxue
Jessica Yuan James Surles. (2015). Investigating relationships between internal marketing practices and employee organizational commitments in the foodservice industry. International Journal of Contemporary Hospitality Management, Vol. 27 Iss 7 pp. 1618 - 1640.

Ikwukananne, Udechukwu I. (2006). The Relationship Between Job Satisfaction, Organizational Commitment, Intent to Quit, and Perceived Alternative Employment in The Assessment of Employee Turnover: A Study of Correctional Officers. Dissertation. Nova Southeastern University.

Ismail, Azman \& Mohd Ridwan Abd Razak, 2016. Job Satisfaction as a Determinant of Organizational Commitment, Journal of Contemporary Issues and Thought Vol. 6, 2016 (10-18)

Kasim Randeree \& Abdul Ghaffar Chaudhry, (2012),"Leadership - style, satisfaction and commitment", Engineering, Construction and ArchitecturalManagement, Vol. 19 Iss 1 pp. $61-85$.

Malhotra, Naresh K.. (2010). Marketing Research: An Applied Orientation (6th ed.). New Jersey: Pearson.

Morris, Ted (1995); "Employee satisfaction: maximizing the return on human capital ". CMA - The Management Accounting Magazine, vol.69, no.10, pp. 15-18, 1995.

Randeree, Kasim and Abdul Ghaffar Chaudhry. (2012). Leadership - style, satisfaction and commitment. Engineering, Construction and Architectural Management, Vol. 19 Iss 1 pp. 61-85.

Reio Jr., Davis M. and Robinson Thomas G. (2012). Benefits of mentoring African-American men. Journal of Managerial Psychology, Vol. 27 Iss 4 pp. 406 - 421.

Samuel K. Sejjaaka and Twaha K. Kaawaase, (2014) "Professionalism, rewards, job satisfaction and organizational commitment amongst accounting professionals in Uganda", Journal of Accounting in Emerging Economies, Vol. 4 Issue: 2, pp.134-157, https:// doi.org/10.1108/JAEE-01-2012-0003

Sejjaaka, Samuel K \& Twaha K. Kaawaase, 2014. Professionalism, rewards, job satisfaction and organizational commitment amongst accounting professionals in Uganda, Journal of Accounting in Emerging Economies, Vol. 4. No. 2, 2014.

Yu-Chang Huang, (2004). Job Satisfaction and Organizational Commitment Among Faculty at Taiwan Higher Education Institution. Dissertation. University of Nebraska.

Zakkariya K.A, George (2015). Job related stress and job satisfaction: a comparative study among bank employees. Journal of Management Development, Vol. 34 Iss 3 pp. $316-329$. 